\title{
Democratic Attitudes and Political Participation in the Developing World
}

\author{
Youngho Cho
}

\begin{abstract}
Prior studies on political culture and democratization in the developing world have focused on either democratic attitudes or political participation. Few, however, have examined the relationship between the two. In this paper, I argue that citizens in developing countries tend to participate in democratic politics because they are attitudinally attached to democracy. Although the structural conditions for political participation such as democratic experience and resources are deficient in the developing world, citizens with strong and deeply held attitudes toward democracy compensates for this deficit. Using data from 23 transitioning and newly democratic countries listed in the fifth World Values Survey and multilevel modeling, I confirm the positive relationship between democratic attitudes and political participation. My findings shed new light on how public attitudes toward democracy enhance active political life in the developing world.
\end{abstract}

Key Words: democratic attitudes, political participation, democratization, developing world, political culture

$\mathbf{P}$ olitical participation is the most important and necessary part of democratic change and governance. In advanced and Western democracies, citizens' political involvement is maintained by four social factors (Norris 2002; Verba, Schlozman, and Brady 1995). First, political engagement among ordinary people is a part of political culture in Western democracies. Youth learn civic norms, duties, and ideas within the family and school during their socialization period and then internalize those values as part of their political orientations. Among those norms, duties, and ideas, political participation is regarded as one of the most important requirements for good and responsible citizens. Second, political parties in advanced democracies articulate a variety of public demands, mobilize their constituents, and connect governmental policies and citizens' demands. In

*Youngho Cho (younghocho94@gmail.com) is an assistant professor at the department of political science in Sogang University. His research includes democratization and political culture. His papers appear in Political Studies and Political Reasearh Quarterly.

This research was supported by Social Science Korea program through the National Research Foundation of Korea(NRF) funded by the Ministry of Education(NRF-2013S1A3A2055205).

The Korean J ournal of International Studies Vol.13-1 (April 2015), 63-87.

http://dx.doi.org/10.14731/kjis.2015.04.13.1.63

(c) 2015 The Korean Association of International Studies 
those societies, attentive publics know which party represents their interests. Third, most Western democracies are economically developed. Economic development provides citizens with appropriate resources to enable their participation in democratic politics. Fourth, political leaders in those societies are accountable and responsive to their electorate as a result of the desire to be reelected, as compared to leaders in developing countries. These four social factors collectively sustain a certain level of political engagement among ordinary citizens in advanced democracies.

How do citizens manifest various forms of political participation in developing countries where there is a deficit in these four factors? Although democratic institutions are installed as a formal structure of politics, democratic ideas, norms, and values are not yet embedded in the political culture in developing societies (Diamond 1999). Traditional political culture is still prevalent and coexists with modern democratic political institutions. Political parties in the developing world are not institutionalized. They do not have strong, persistent ideologies, and single parties frequently disintegrate or unite with others in order to pursue temporary electoral benefits. Economically, these countries are poor, with some exceptions such as Singapore, South Korea, and Taiwan. Many citizens in those countries spend all of their energy to maintain family life and, thus, are not able to express their interest in democratic politics. In short, the cultural, institutional, economic, and political foundations of mass participation have not solidified in the developing world.

Considering these deficits, it is important to ask why some citizens in the developing world are active in democratic politics whereas others are not; mass political participation is not only an essential part of democratic politics but also a crucial factor in the development of democracy (Diamond 1999; Norris 2002). In this study, I argue that citizens in transitioning and non-Western societies become actively engaged in democratic politics because they believe in the legitimacy of democracy as a political system.

The political legitimacy of democracy is less crucial in terms of citizen-planned political actions in advanced democracies because the democratic political system has been long taken for granted in those societies. Those citizens do not need to deepen their attitudes toward a democratic political system in a functional sense. Instead, they tend to be interested in detailed components of democratic politics, including ideologies, parties, and policies (Converse 1964; Dalton 2013).

However, structural conditions that favor vibrant democratic politics are deficient in the developing world and, thus, democracy is still in competition with its alternatives in those countries. In the eyes of ordinary people, mass participation is not a necessary part of political life but can be a result of deliberative decision- 
making in which citizen attitudes about democracy play a role. Where the structural conditions for mass participation are not sufficient, individual attitudes toward democracy is one of the more important psychological forces that lead ordinary citizens to participate in politics.

Specifically, it is reasoned that democratic citizens who want their society to become democratic, who are informed of concepts of democracy and who desire to live in a democratic system, are likely to be active in political participation. I define these psychological orientations as a positive attitude toward democracy as a whole. Those with such orientations toward democracy are likely to take part in the politics of the developing world compared with those who are unsupportive of democracy and indifferent to it. As Almond and Verba (1963) emphasized, attitudes toward democracy form the latent tendencies of political behaviors and influence political actions. I subject this long-standing thesis to an empirical test, analyzing public opinion data from 23 developing countries included in the fifth World Values Survey.

\section{CONCEPTUALIZATION AND THEORIZATION}

In the early 1990s, as democracy spread outside the Western world after the fall of the Berlin Wall, individual scholars and research institutes conducted public opinion surveys in a large number of democratizing countries and found surprising evidence that popular support for democracy or democratic values was high in new democracies and even in nondemocratic countries (Gibson, Duch, and Tedin 1992; Nathan and Shi 1993). These findings conflicted with the theoretical expectation of political culture and democratization perspectives that claimed the cultural foundation of democracy was relatively stable in advanced democracies but minimally existed in authoritarian societies. Some scholars questioned whether mass political culture matters with regard to the stability of democracy (Jackman and Miller 1996). However, many others discussed whether the early literature correctly conceptualized and measured central concepts of political culture, especially democratic attitudes, and thus, suspected that this surprising conundrum stemmed from a measurement problem as well as a misconceptualization of democratic attitudes (Booth and Seligson 2009; Norris 1999).

In this study, I follow Almond and Verba's (1963) conceptualization of democratic attitudes and define it as a multidimensional construct that refers to a set of generalized orientations toward a democratic political system. Specifically, I posit that a positive attitude towards democracy is a multidimensional phenomenon consisting of three distinct but related components: affection, cognition, and 
conation toward democracy. In other words, as a latent second-order construct, positive democratic attitudes can be traced from affective, cognitive, and conative responses as first-order factors of democracy at the regime level (Ajzen 2005).

The affective component indicates preferences towards democracy and authoritarianism. A critical mass of citizens becomes affectively committed to democracy when those citizens prefer democracy to authoritarianism (Inglehart 2003). In the developing world, where a number of countries have experienced democratic transitions, the cultural norms of the previous authoritarian regimes tend to coexist with the newly or partially installed institutions and procedures of democracy. To ordinary citizens with little experience in democratic politics, democracy is one of many alternatives. Consequently, a rise in their democratic preferences does not necessarily lead to a corresponding reduction in their preferences for authoritarianism, or vice versa. For this reason, I view affective orientations as dynamic phenomena because committed attitudes toward democracy involve a choice between democratic and authoritarian regime types and require democratic citizens to support democracy and reject its alternatives simultaneously (Rose, Mishler, and Haerpfer 1998).

The cognitive component of democratic attitudes refers to citizen understanding about democracy. In a transitional society, most citizens lack experience with democratic politics, are not familiar with an imported political system of democracy from the West, and, thus, do not have a sophisticated understanding of it. To take part in democratic politics, citizens need to first learn the term democracy and understand that it describes a system that is different from authoritarianism. Without the cognitive understanding to discriminate between democracy and authoritarianism, citizens will not be able to root out authoritarian forces and replace them with democratic ones (Welzel 2013). Thus, it is democratic citizens informed about democracy who tend to participate politically and use their participation as an instrument to promote democracy. As O'Donnell, Schmitter, and Whitehead (1986) warned, in circumstances where a majority of citizens are ignorant of democracy, mass participation would be impossible and the collapse of a dictatorship may not necessarily lead to the establishment of democracy but would likely be replaced by another type of dictatorship.

The conative component involves behavioral intention towards democracy. Favorable orientations towards, and sophisticated understanding of, democracy are useless in terms of effective political participation if citizens do not have the conative intention to live in a country that is governed democratically. An increasing number of citizens in advanced democracies are dissatisfied with the performance of democracy; yet, they are still supportive of democracy and do not desire to live in any other political system. On the other hand, many citizens of new 
democracies suffer from democratic-reform fatigue because democratic transition and consolidation must involve political transformation from authoritarian to democratic institutions; this transformation hinders new democratic regimes from producing strong performance outcomes to satisfy citizens' inflated social and political demands during the transitional period. Under this situation, they tend to ponder authoritarianism with nostalgia and are reluctant to take part in the political process (Chu, Chu, and Park 2007; Crow 2010). Despite this trend, however, it is expected that those with a strong willingness to live in a democratic political system would retain their participatory intention.

Scholars in advanced democracies have found that ordinary citizens have greater participation because they accept democratic values and support the political system (Almond and Verba 1963; Booth and Seligson 2009; Kornberg and Clarks 1992; Lipset 1960; Muller 1977; Norris 1999). When theorizing political support for democracy and democratic stability, these scholars identify political participation as a function of the former and an instrument of the latter. However, not all forms of participation are conducive to democratic stability. It is well known that political support for democratic values breeds conventional participation, whereas political alienation from those values fuels unconventional behaviors such as protest activity.

This conventional wisdom does not hold in the context of transitioning countries where democratic and authoritarian forces struggle to take power in various political arenas. In these countries, political cleavages divide citizens into one group that is democratically oriented and another that is positively oriented toward the existing legacies of authoritarianism (Diamond 1999; Rose, Mishler, and Haerpfer 1998). Democratic activists and opinion leaders tend to target the first group, activating their positive attitudes towards democracy and bringing them into political battlefields, either formal or otherwise. As a corollary, it is expected that citizens with a strong democratic attitude are more likely to take part in various forms of participation.

\section{MEASURING DEMOCRATIC ATTITUDES}

The previous section made clear that positive democratic attitudes consist of affective, cognitive, and conative components. These three components are represented by democratic support, understanding, and willingness to live in a democracy, respectively. This section measures each of the three components, counts them to construct the depth of democratic attitudes, and introduces their distribution across countries in the developing world. 
To measure democratic support for the affective component, I used a set of three questions from the World Values Survey. These three questions measured citizens' affective orientations for democracy, military dictatorship, and civilian dictatorship (see Appendix A for the chosen questions and others from the survey). Using these three measurements, this study identified committed democratic supporters as those who are fully supportive of democracy and reject both military and civilian dictatorships (Inglehart and Welzel 2005).

To estimate democratic understanding for the cognitive component, I used a set of four questions from the World Values Survey that asked global citizens about four regime characteristics and had them evaluate how essential each characteristic was to democracy. As a close-ended question, respondents evaluated four propositional statements representing the four regime characteristics on a 10point scale, with 1 referring to "not at all an essential characteristic of democracy" and 10 referring to "an essential characteristic of democracy." The four regime characteristics are popular elections, protection of civil liberties, military takeover, and religious interpretation of law. Obviously, the first two are the core characteristics of democracies and the latter two are the most common characteristics of current authoritarian countries around the world (Dahl 1971; Munck 2009). Analytically, the core of democratic understanding is whether citizens are able to distinguish democracy from authoritarianism. In short, if citizens know that democracy is different from authoritarianism, they would rate these contradictory groups of regime characteristics differently. When dichotomizing the 10point scale into inessential (1-5) and essential (6-10), this study considered informed democratic citizens as those who rate the two democratic characteristics as essential to democracy and the two authoritarian ones as inessential (Cho 2015).

In order to measure the conative component of positive democratic attitudes, I used one question from the World Values Survey: "How important it is for you to live in a country that is governed democratically?" Respondents expressed their conative intention toward democracy on a 10-point scale, with 1 referring to "not at all important" and 10 referring to "absolutely important." To simplify the testing process of the conative intention, I divided the 10-point scale into two parts: inessential (1-5) and essential (6-10). I considered those answering the latter (essential) as having a strong desire to live in a democracy.

Finally, the depth of democratic attitudes is measured by counting its three components (Petty and Krosnick 1994). As discussed previously, positive democratic attitudes are higher-order constructs consisting of affective, cognitive, and conative responses to democracy. To better understand the nature of democratic attitudes, I viewed its depth as a composite index of democratic attitudes. I 
assumed that an individual who is affectively supportive of democracy over authoritarianism cognitively discriminates between them, and someone who has the conative intention to live in a democracy has strong feelings towards democracy as a political regime. From this perspective, I counted the most democratic type of the three components, which ranged from o to 3 points. For example, a respondent would score 3 when he or she belonged to the committed type in the affective component, the informed type in the cognitive component, and the strong desire type in the conative component.

To examine distribution of democratic attitudes in the developing world, I used public opinion data from the fifth World Values Survey conducted during the period 2005-2008. The World Values Survey investigated social and political values among more than 80,000 people across 57 societies. I restricted the sample countries to transitioning countries and new democracies, excluding authoritarian countries because advanced Western democracies, transitioning countries, and stable authoritarian states are qualitatively different. Democratic attitudes may not matter in the functioning of advanced Western democracies. In those countries, leading scholars have studied other civic virtues such as ideological dispositions and political tolerance rather than individual attitudes towards democracy as a political system (Converse 1964; Gibson 2007). In stable authoritarian countries, political participation is substantially restricted. I expect that citizens' orientations towards democracy would affect political participation in societies experiencing democratization and liberalization even to a low degree. This qualification resulted in a sample of 23 transitioning countries and 32,424 respondents. Although the sample is small considering that there are more than 100 transitioning countries in the developing world, it covers the maximum number of countries where all the relevant questions were asked and that have experienced democratic reforms in a recent period. 
The Korean Journal of International Studies 13- 1 | 70

Table 1. Distribution of Democratic Attitudes and Components across Developing Countries

\begin{tabular}{|c|c|c|c|c|c|}
\hline Region & Country & $\begin{array}{l}\text { Affection } \\
\text { (\% of the } \\
\text { Committed) }\end{array}$ & $\begin{array}{l}\text { Cognition } \\
\text { ( } \% \text { of the } \\
\text { Informed) }\end{array}$ & $\begin{array}{l}\text { Conation } \\
\text { (\% of High } \\
\text { Willingness) }\end{array}$ & $\begin{array}{c}\text { Depth of } \\
\text { Democratic } \\
\text { Attitude }\end{array}$ \\
\hline \multirow{9}{*}{$\begin{array}{l}\text { Eastern } \\
\text { Europe }\end{array}$} & Bulgaria & $24 \%$ & $33 \%$ & $84 \%$ & 1.35 \\
\hline & Germ-E. & 69 & 76 & 94 & 2.38 \\
\hline & Moldova & 27 & 40 & 85 & 1.48 \\
\hline & Poland & 48 & 42 & 91 & 1.74 \\
\hline & Romania & 17 & 34 & 90 & 1.33 \\
\hline & Serbia & 46 & 36 & 83 & 1.57 \\
\hline & Slovenia & 64 & 46 & 82 & 1.85 \\
\hline & Ukraine & 20 & 30 & 85 & 1.28 \\
\hline & Pooled & 36 & 40 & 85 & 1.54 \\
\hline \multirow{5}{*}{$\begin{array}{l}\text { Latin } \\
\text { America }\end{array}$} & Brazil & 26 & 29 & 87 & 1.39 \\
\hline & Chile & 54 & 33 & 87 & 1.69 \\
\hline & Peru & 34 & 26 & 88 & 1.44 \\
\hline & Trin-Tob & 49 & 26 & 90 & 1.64 \\
\hline & Pooled & 39 & 28 & 88 & 1.51 \\
\hline \multirow{6}{*}{$\begin{array}{l}\text { Africa } \\
\text { Burkina }\end{array}$} & Burkina & 31 & 30 & 82 & 1.33 \\
\hline & Ethiopia & 54 & 18 & 97 & 1.69 \\
\hline & Ghana & 65 & 21 & 98 & 1.83 \\
\hline & Mali & 23 & 14 & 78 & 1.08 \\
\hline & South Africa & 40 & 19 & 93 & 1.49 \\
\hline & Pooled & 43 & 21 & 91 & 1.51 \\
\hline \multirow[t]{7}{*}{ Asia } & India & 21 & 16 & 46 & 0.71 \\
\hline & Indonesia & 3 & 13 & 92 & 1.03 \\
\hline & Malaysia & 23 & 11 & 90 & 1.25 \\
\hline & South Korea & 39 & 52 & 94 & 1.86 \\
\hline & Taiwan & 37 & 61 & 96 & 1.93 \\
\hline & Thailand & 16 & 20 & 95 & 1.31 \\
\hline & Pooled & 25 & 23 & 87 & 1.29 \\
\hline \multicolumn{2}{|l|}{ Pooled } & 36 & 28 & 88 & 1.46 \\
\hline
\end{tabular}

Source: The fifth World Values Surveys 
Table 1 shows the distribution of the three components and the depth of democratic attitudes across countries in the developing world. Generally, only $36 \%$ of the citizens in the developing world simultaneously supported democracy and rejected authoritarianism. Moreover, only 28\% of them successfully distinguished democracy from authoritarianism. However, about nine out of ten citizens expressed strong willingness to live in a democracy. This picture shows that although an overwhelming number of citizens desire to live in a democracy, they are neither affectively committed to democracy nor cognitively sophisticated about it. A careful comparison at the regional level shows great variation across regions. About two out of four individuals in Eastern Europe, Latin America, and Africa are committed to democracy, whereas only one of four people in Asia is committed. In terms of the cognitive component, Eastern Europe is the most informed region with regard to democracy in that $40 \%$ of its citizens are able to discriminate between democracy and authoritarianism. In the three other regions, those informed about democracy range from $21 \%$ in Asia to $28 \%$ in Latin America. At the country level, economically developed countries with democratic experience are high in the affective and cognitive components. For example, more than $40 \%$ of the citizens in East Germany, Poland, and Slovenia are either committed to democracy or informed about democracy. More than $30 \%$ of the people in Poland, Serbia, Slovenia, Chile, Burkina Faso, South Korea, and Taiwan were scored as either committed in the affective component or informed in the cognitive component. Finally, those informed and committed democratic citizens were extremely few in Romania, Mali, India, Indonesia, and Thailand. Overall, democratic citizens who have the desire to live in a democracy, who are unconditionally commitment to democracy, and who possess some level of understanding about democracy constitute only a minority and vary across countries.

\section{EXISTING THEORIES OF POLITICAL PARTICIPATION}

The argument made for this study suggests that citizens holding strong attitudes towards a new political system of democracy were more active in democratic politics than those having weak attitudes because they were affectively supportive of democracy over authoritarianism, cognitively informed of democracy, and conatively willing to live in a democracy. The empirical analysis of political participation must consider the relevant theories. This study considers three major theories as competing models: resource, social capital, and political culture.

First, the resource model developed by Verba and his colleagues argues that the more resources citizens possess, the more easily they are able to participate 
because their resources reduce the costs of participation (Verba, Schlozman, and Brady 1995). According to this model, political participation is a marginally costly behavior for citizens. Thus, citizens with sufficient resources are more likely to participate than other citizens with fewer. Although Verba and colleagues emphasized many types of resources, education is a consensus indicator promoting political participation by enhancing civic skills and individual social networks. Moreover, affluent people have more time and money to pay attention to politics than poor people because the latter spend most of their energy maintaining their lives. The extra time and resources wealthy individuals utilize allow them to take part in politics (Verba, Schlozman, and Brady 1995). Although formal education is a primary source of citizens' cognitive resources, subscribing to mass media also increases the cognitive component. By following newspapers and TV/radio broadcasts, they are likely to be politically active and become sophisticated about political issues, which helps them participate further. Thus, I include three variables for the resource model: (1) formal education; (2) income; and (3) media use.

Second, the social capital model began with the observation that participation in democratic politics is active where voluntary civic associations are well established and citizens trust their government and each other (Putnam 1993). According to Putnam, citizens in civic associations demand more effective public services and are prepared to act collectively to achieve their shared goals. In this process, civic associational life bridges citizens, preventing them from becoming alienated (acts as a kind of social glue) and helping them to participate in the political process (gears of power). Furthermore, Putnam (2000) argues that communities with high social capital act as schools for improving civility, and citizens in these communities learn civic skills and norms. Three indicators represent the social capital model: (1) citizens' membership in civic organizations; (2) political trust in three national political institutions (government, parliament, and political parties); and (3) interpersonal trust.

Third, theories of political culture argue that political participation is shaped by individual differences in political values. Although different scholars have identified many values as related to mass political behaviors, I focus on two particular theories: self-expression and authoritarian socialization. Although Inglehart and his colleagues do not specifically point out the relationship between self-expression values and political participation, their studies clearly imply that the former enhances the latter (Inglehart and Welzel 2005). According to them, especially in the developing world, self-expression values are perfectly compatible with a participatory culture and have the potential to transform authoritarian norms and values into democratic ones. Consequently, it is reasoned in this model that higher self-expression values are related to active participation in democratic politics. 
Furthermore, theories of socialization claim that political attitudes and behaviors are learned early in life, are crystallized into a culture, and rarely change throughout one's lifetime (Almond and Verba 1963). By teaching dominant values, norms, and ideology during the socialization period, a society integrates individuals into its political system, keeps a large proportion of the individuals involved in politics, and finally, maintains stable social order (Rose, Mishler, and Haerpfer 1998). This implies that learning modes of political participation in democratic politics depends on whether individuals have an opportunity to learn those modes early in life. If citizens grew up in a democratic setting, they were likely to learn the importance of political participation in democratic politics because their society taught it. On the other hand, those citizens socialized under authoritarianism have a disadvantage in learning about political participation because they did not learn it during their socialization period. Therefore, I include two variables for the political culture model: (1) self-expression values and (2) an authoritarian socialization dummy variable for those who have spent more than 20 years under authoritarianism during their early lives.

In addition to these core control variables, I consider several basic control factors. Political interest is known to promote political participation among individual citizens. Older ages indicate more social and political experiences. Older generations have raised their children, been involved in local issues, and felt more responsible for political outcomes. Accordingly, a positive correlation between age and political participation is expected. However, considering the last few decades of democratic and economic development in the developing world, younger generations were exposed more to democratic politics and were better educated, whereas older people were socialized and spent most of their lives under dictatorships. Therefore, including the age variable would shed light on how political participation changes in the developing world as people get older. Moreover, women in the developing world face societal pressure to learn traditional norms and become interested in different associations than men do. This implies that women in the developing world are less active in political participation than men. As a result, I include (1) political interest, (2) age, and (3) a female dummy variable measure.

In addition, two country-level variables are included: economic development and level of democracy. According to modernization theories, socioeconomic modernization tends to bring urbanization, the spread of mass media, expansion of public education, rising income, and economic diversification. These socioeconomic changes place social resources in the hands of ordinary people, and this enhances their capabilities to organize political actions. As a country becomes democratized to allow civil liberties and political rights, democratic ideas and 
news become available in the political market. In contrast, the ideas and news related to democracy are not likely to proliferate in nondemocratic societies because authoritarian governments control the flow of ideas and news. The cheap cost of obtaining political information and the open environment, which allow political complaints, improve political participation among citizens. Thus, I include (1) Ln(GDP per capita) for economic development and (2) a reversed Freedom House rating for level of democracy.

\section{DEPENDENT VARIABLES AND EMPIRICAL MODEL}

To test the role of positive democratic attitudes on individual political participation, I used three indicators of political participation: voting, petition, and boycott. Voting is the most popular and conventional form of political engagement for mass publics in a democracy (Verba, Schlozman, and Brady 1995). Moreover, people take such direct actions as signing petitions and engaging in boycotts, which belong to unconventional participation (Norris 2002). As a dichotomous variable, these three dependent variables are measured by whether individuals participated in each of these specific forms of political participation.

These dependent variables have been widely used by scholars studying political participation in a comparative perspective (Booth and Seligson 2009; Norris 2011). However, a methodological caution should be added with regards to this practice. Democratic attitudes are relatively latent and stable, whereas political actions are dynamic. When using the former as a determinant of the latter, one would be unable to trace a causal dynamic of how individual citizens take political action without a panel survey. Because such a panel survey is rare, with some exceptions (Gibson 1996), most scholars in this field have used cross-national survey data (Almond and Verba 1963; Inglehart and Welzel 2005). In this study, I adopted this conventional approach and have attempted to provide an empirical analysis of the connection between democratic attitudes and political participation in the developing world.

Given that the World Values Survey has a hierarchical data structure having both individual-level and country-level variables, this paper uses multilevel statistical models. Multilevel modeling is developed to estimate the simultaneous effects of both individual- level and country-level variables (Raudenbush and Bryk 2002). To analyze the multilevel data, political scientists used either a series of country dummy or interaction terms of individual and country variables. However, these conventional approaches overestimate the degrees of freedom and underestimate standard errors, thereby causing the significance test to be 
inaccurate (Steenbergen and Jones 2002). In short, the conventional approaches are fundamentally limited in dealing with the varying nature of intercepts and slopes across countries in multilevel survey data. On the other hand, by allowing intercepts and slopes to vary by country, multilevel modeling enables the researcher to estimate country-specific intercepts and slopes in an unbiased way. Because this study presents binary dependent variables of political participation, it uses multilevel binary models to test the effects of various independent variables. When the dependent and independent variables are considered together, the basic equation is identified as follows:

$\mathrm{Y}($ Political Participation $)=\gamma \mathrm{OO}+\gamma \mathrm{01}(\ln [$ GDP per capita] $)+\gamma \mathrm{0} 2($ Freedom House Reversed $)+\gamma 10$ (Positive Democratic Attitude $)+\gamma 20$ (Education) $+\gamma 20$ (Income) $+\gamma 60$ (Media Use) $+\gamma 70$ (Membership in Civic Organizations) $+\gamma 40$ (Political Trust) $+\gamma 40$ (Interpersonal Trust) $+\gamma 40$ (Self-expression Values $)+\gamma 80$ (Authoritarian Socialization Dummy) $+\gamma 30$ (Political Interest) $+\gamma 90$ (Age) $+\gamma 100$ $($ Female Dummy $)+$ uo $+\varepsilon$

\section{EMPIRICAL RESULTS}

To investigate the effect of democratic attitudes on both conventional and unconventional forms of political participation, I begin the empirical analysis by running multilevel models for voting, petition, and boycott with fixed effects. The results in Table 2 make it clear that positive attitudes towards democracy are strongly associated with political participation among citizens in the developing word. As expected, an increase of one standard deviation in the depth of democratic attitudes leads to a $15 \%$ rise in the odds of turning out to vote, holding all other factors constant. Pro-democratic attitudes are also positively related with petition, but its effect is not statistically significant. Democratic attitudes have a positive and statistically significant effect on boycott, increasing by $15 \%$ the odds of participating in a boycott. This result suggests that democratic citizens with unconditional commitment to democracy, informed understanding about it, and strong willingness to live in a democracy are more active in political participation. Because they want their countries to be democratic, know that democracy is different from authoritarianism, and desire to live in a democracy, their strong attitude towards democracy drives them to be actively engaged in democratic politics. 
The Korean Journal of International Studies 13- 1 | 76

Table 2. Multilevel Analysis for Democratic Attitudes and Political Participation

\begin{tabular}{|c|c|c|c|c|c|c|}
\hline \multirow[b]{2}{*}{ Variables } & \multicolumn{2}{|c|}{ Voting } & \multicolumn{2}{|c|}{ Petitioning } & \multicolumn{2}{|c|}{ Boycott } \\
\hline & Beta & $\begin{array}{l}\text { Odds } \\
\text { Ratio }\end{array}$ & Beta & $\begin{array}{l}\text { Odds } \\
\text { Ratio }\end{array}$ & Beta & $\begin{array}{l}\text { Odds } \\
\text { Ratio }\end{array}$ \\
\hline Depth of Democratic Attitudes & $0.08^{* * *}$ & 1.15 & 0.05 & 1.05 & $0.14^{* * *}$ & 1.15 \\
\hline \multicolumn{7}{|l|}{ Resource Model } \\
\hline Education & $0.14^{* * *}$ & 1.30 & $0.29^{* * *}$ & 1.34 & $0.26^{* * *}$ & 1.30 \\
\hline Income & -0.01 & 0.92 & $-0.07^{* *}$ & 0.93 & $-0.08^{* * *}$ & 0.92 \\
\hline Media Use & $0.14^{\star * *}$ & 1.08 & $0.13^{* * *}$ & 1.13 & $0.08^{* * *}$ & 1.08 \\
\hline \multicolumn{7}{|l|}{ Social Capital Model } \\
\hline Membership in civic organizations & -0.01 & 1.37 & $0.27^{\star \star *}$ & 1.31 & $0.31^{\star * *}$ & 1.37 \\
\hline Political trust & $0.12^{* * *}$ & 0.97 & -0.02 & 0.98 & -0.03 & 0.97 \\
\hline Interpersonal trust & $0.04^{* *}$ & 0.99 & 0.02 & 1.02 & -0.01 & 0.99 \\
\hline \multicolumn{7}{|l|}{ Political Culture Model } \\
\hline Self-expression values & $-0.11^{\star * *}$ & 1.22 & $0.16^{* * *}$ & 1.18 & $0.20^{\star * *}$ & 1.22 \\
\hline Authoritarian socialization & $0.07^{* * *}$ & 1.10 & $0.09^{* *}$ & 1.09 & $0.09^{* * *}$ & 1.10 \\
\hline \multicolumn{7}{|l|}{ Others } \\
\hline Political interest & $0.33^{* * *}$ & 1.53 & $0.43^{* * *}$ & 1.53 & $0.42^{* * *}$ & 1.53 \\
\hline Age & $0.70^{* * *}$ & 1.05 & 0.04 & 1.04 & 0.05 & 1.05 \\
\hline Female & 0.02 & 0.86 & $-0.22^{* * *}$ & 0.80 & $-0.15^{\star * *}$ & 0.86 \\
\hline \multicolumn{7}{|l|}{ Counntry-Level Variables } \\
\hline Ln (GPD per capita) & -0.07 & 0.55 & $-0.37^{*}$ & 0.69 & $-0.60^{* * *}$ & 0.55 \\
\hline Reversed Freedom House Rating & -0.13 & 1.67 & 0.11 & 1.12 & $0.51^{* * *}$ & 1.67 \\
\hline Variance Components & \multicolumn{2}{|c|}{$0.65^{\star * *}$} & \multicolumn{2}{|c|}{$0.51^{* * *}$} & \multicolumn{2}{|c|}{$0.37^{* * *}$} \\
\hline$-2 \times$ loglikelihood & \multicolumn{2}{|c|}{-33470} & \multicolumn{2}{|c|}{-34122} & \multicolumn{2}{|c|}{-34038} \\
\hline Number of obs & \multicolumn{2}{|c|}{24,088} & \multicolumn{2}{|c|}{24,088} & \multicolumn{2}{|c|}{24,088} \\
\hline Number of groups & \multicolumn{2}{|r|}{23} & \multicolumn{2}{|r|}{23} & \multicolumn{2}{|r|}{23} \\
\hline
\end{tabular}

Note: Significance level: ${ }^{*} p \leq 0.05 ;{ }^{* *} p \leq 0.01 ;{ }^{* *} p \leq 0.001$.

Beta: Standardized coefficient

Source: The fifth World Values Survey

This finding is different from the conventional wisdom shared among scholars of advanced democracies in that political support for democracy increases conventional participation while decreasing unconventional participation (Muller 1977). In the developing world, political attitudes towards democracy appear to be conducive to both conventional and unconventional behaviors. This finding was consistent with Huntington's argument that strong attitudinal attachment to 
democratic values and norms, especially among younger generations, led to popular demand for democratic reforms during the 1960s-1970s in the United States (1981). Moreover, the finding is also supportive of the recent cross-national studies that show that assertive and active citizens push democratic change forward more than allegiant and passive ones do (Dalton and Welzel 2014; Norris 2011)

Among the indicators of the resource model, education and media use have a consistently positive effect on the three forms of political participation. However, income is negatively associated with all three dependent variables, which suggests that wealthier people in the developing world do not attempt to take part in politics. Instead, they are likely to be distant from politics. It lends support to Rueschemeyer's thesis that people in the upper middle class have an ambiguous attitude towards democratic politics (Rueschemeyer, Stephens, and Stephens 1992). Among those three independent variables, the effect of education is strong, producing about a $30 \%$ increase in the odds of participating in the three forms of participation. This result indicates that to promote political participation among ordinary people in the developing world, expansion of formal education and diffusion of mass media are crucial. Thus, modernization is crucial for enhancing mass political participation (Diamond 1999; Lipset 1960).

In the model of social capital, the results show a clear comparison between the associative dimension and the psychological dimension. In the associative dimension, membership in civic organizations was positively related to petition and boycott and its effects were very strong, whereas it was negatively associated with voting. Political trust and interpersonal trust were positively related only to voting. This pattern suggests that associative membership in a social capital organization promotes direct forms of political participation, whereas trust, whether political or interpersonal, advances conventional forms. In other words, organized civic activities are a necessary condition for new forms of political engagement, whereas turnout can be improved by the psychological factor of trust, whether political or interpersonal. Despite the difference between the associative and psychological aspects, the result makes it clear that social capital matters to mass political participation and democratic politics (Putnam 1993).

Within the political culture model, both variables are statistically significant. Strikingly, authoritarian socialization does not hinder political participation. On the contrary, it facilitates both conventional and new forms of political engagement. Although some citizens are socialized under authoritarianism, waves of global democratization over the last three decades have suppressed the negative effect of authoritarian socialization. Instead, citizens experiencing both authoritarianism and democracy are more actively engaged in politics. Self-expression values are positively related to new forms of political participation but negative- 
ly related to conventional forms. Moreover, their effects are very strong, either increasing or decreasing the odds by $20 \%$ in all three forms of participation. This means that citizens with strong self-expression values are very active in direct actions and inactive in regular voting. Instead of waiting for regular election days, they prefer to initiate and organize direct actions. This result clarifies Inglehart's postmodernization thesis that self-expression values are an important driving force to democratize non-democratic countries and make new democracies work (Inglehart and Welzel 2005). The finding shows the limited effects of self-expression values in promoting political participation in the developing world. Although they facilitate direct actions in the political arena, they hurt the development of electoral institutions.

As expected, political interest is the strongest of the control variables, increasing by $50 \%$ the odds of participating in each of the three actions. Age is shown to be related only to voting; it has no relation to direct actions. As individuals become older, voting in regular elections becomes routine, whereas older voters are not active in petition and boycott because direct actions require political motivation, reasoning, and mobilization (Verba, Schlozman, and Brady 1995). In the developing world, women are likely to be less active in petitions and boycotts. This could be explained by the fact that the social and economic activities of women are culturally restricted to the home or local associations in developing countries (Norris 2002). It is interesting that economic development hinders mass participation in petitions and boycotts, yet democratic development facilitates boycotts.

All in all, individual attitudes towards democracy matter to a citizen decision to take part in politics. The depth of his or her attitude towards democracy appears to facilitate participatory orientations among them. In other words, democratic citizens in the developing world tend to consider participation as part of their political life because they want their country to be democratic and are attached to the democratic political system. Although the effects of democratic attitudes are not greater than variables relevant to participation such as education and political interest, they are consistent across various forms of political participation.

\section{CLOSER LOOK AT DEMOCRATIC ATTITUDE COMPONENTS AND POLITICAL PARTICIPATION}

The previous section made it clear that those positive attitudes towards democracy as a whole influence individual political participation in the developing world. If democratic attitudes have such a positive effect on political behaviors, 
which components are crucial? I ran multilevel models of political participation on each of the three attitude components. Because I focused on the comparison of the effects of the democratic attitude components on political participation, the coefficients of the control variables are not reported in Table 3 .

Table 3. Comparison of the Effects of Democratic Attitude Components on Political Participation

\begin{tabular}{l|c|c|c|c|c|c}
\hline \multirow{2}{*}{} & \multicolumn{2}{|c|}{ Voting } & \multicolumn{2}{c|}{ Petitioning } & \multicolumn{2}{c}{ Boycott } \\
\cline { 2 - 6 } & Beta & $\begin{array}{l}\text { Odds } \\
\text { Ratio }\end{array}$ & Beta & $\begin{array}{l}\text { Odds } \\
\text { Ratio }\end{array}$ & Beta & $\begin{array}{l}\text { Odds } \\
\text { Ratio }\end{array}$ \\
\hline $\begin{array}{l}\text { Affection } \\
\text { (committed type dummy) }\end{array}$ & $0.07^{* * *}$ & 1.07 & 0.05 & 1.06 & $0.12^{* * *}$ & 1.13 \\
\hline $\begin{array}{l}\text { Cognition } \\
\text { (informedtype dummy) }\end{array}$ & 0.02 & 1.02 & 0.03 & 1.03 & $0.07^{* * *}$ & 1.07 \\
\hline $\begin{array}{l}\text { Conation } \\
\text { (high willingness dummy) }\end{array}$ & $0.07^{* * *}$ & 1.07 & -0.01 & 0.99 & $0.07^{*}$ & 1.07 \\
\hline
\end{tabular}

Note: Significance level: * $p \leq 0.05 ;{ }^{* *} p \leq 0.01 ;{ }^{* *} p \leq 0.001$

Beta coefficients for other variables are not reported

Source: The fifth World Values Survey

Among the three components, the affective component has a positive effect on the three forms of political participation, but its effect on petitioning is not significant. It increases the odds of participation in voting and boycotts by 7 percent and 13 percent, respectively. On the other hand, democratic understanding is positively related to the three forms of political participation, but it is statistically significant only in relation to participation in boycotts. Finally, voting and boycotts are enhanced by citizens' conative willingness to live in a democracy. Because those voters strongly want to live in a democracy, they tend to take part in politics. Nevertheless, its effect is not significant on the likelihood of participating in petitions.

When these components are considered together, political participation is influenced by affection, conation, and cognition, in that order. This is surprising because political information is one of the critical determinants in explaining political participation in the advanced industrial democracies. The results suggest that political involvement of ordinary people in the developing world is more strongly based on affective and conative factors than on cognitive ones. Despite this small difference across the components and the various forms of political action, the general picture drawn from the analysis confirms our original argument that positive attitudes towards democracy and its components facilitate individual political participation in the developing world. 


\section{CONCLUSION}

Over the last four decades, democratic political systems have spread to new places where civic and modern traditions did not exist. An overwhelming number of citizens in the developing world have shown attitudes supportive of democracy and have adopted common forms of political participation necessary for democratic politics and development. This study explored the possibility that in the developing world, with lack of participatory culture and resources creating it, individual attitudes toward democracy affect political participation. Examining the effect of democratic attitudes on both conventional and new forms of political engagement, I provided a detailed picture on the determinants of individual political participation in those developing countries.

In particular, this study empirically examined the effect of democratic attitudes on political participation in 23 countries and four regions. The results lend strong support to the original argument of this study that citizens' attitudes toward a democratic political system influence their decision to participate in various forms of political engagement in the developing world. Given that civic duties, democratic norms, and values are not yet embedded into the political culture, and their democratic experience is limited in the developing and non-Western world, democratic attitudes work as an alternative to them. Specifically, our study showed that political participation is generally active among those democratic citizens who are unconditionally committed to democracy over authoritarianism, cognitively informed of democracy, and behaviorally willing to live in a democracy. Because they have such a strongly and deeply positive attitude toward a new political system of democracy imported from the West, they tend to be participatory in political actions common in democratic politics.

The findings presented here shed new light on the link between political support for democracy and democratic change in the developing world. Prior studies on the cultural approach to democratization have identified public support for democracy as a force promoting democratic stability and deterring authoritarian challenges (Inglehart 2003; Rose, Mishler, and Haerpfer 1998). These studies assume that public attitudes about democracy have only a latent effect on democratic change. My study shows that democratic attitudes have a behavioral and overt effect.

Moreover, the findings presented in this study implied that the traditional model of a democratic citizen does not hold in the current developing world. According to Almond and Verba's (1963) model, democratic citizens are active in the electoral domain and relatively inactive in other domains of participation. They claimed that a mixture of active and passive orientations is an essential ele- 
ment of democratic citizenship and stabilizes democratic politics. However, recent studies contend that citizens supportive of democracy and democratic values demand democratic change regardless of whether participation is conventional or unconventional (Dalton and Welzel 2014; Norris 2011). This new model of democratic citizenship is also found in Putnam's study on local governments in Italy (1993). In his famous book, Making Democracy Work, Putnam showed that citizens with strong civic virtues in northern provinces are assertive in demanding their preferences for local government action, as compared with those passive individuals in the southern provinces. This study provided credible evidence that the traditional model of a democratic citizenship does not hold and that a new model is observed in the developing world because citizens with deeply rooted democratic attitudes are involved in both conventional and unconventional modes of participation.

\section{REFERENCES}

Ajzen, Icek. 2005. Attitudes, Personality and Behavior. New York: Open McGraw-Hill International.

Almond, Gabriel A. and Sidney Verba. 1963. Civic Culture. Princeton: Princeton University Press.

Booth, John and Mitchell Seligson. 2009. The Legitimacy Puzzle in Latin America. New York: Cambridge University Press.

Chang, Yu-tzung, Yunhan Zhu, and Chong-min Park. 2007. "Authoritarian Nostalgia in Asia.” Journal of Democracy 18(3), 66-80.

Cho, Youngho. 2015. "How Well are Global Citizenries Informed about Democracy?” Political Studies 63(1), 240-258.

Converse, Philip. 1964. "The Nature of Belief Systems in Mass Publics.” In David Apter ed., Ideology and Its Discontents. New York: Free Press of Glencoe, 206-261.

Crow, David. 2010. “The Party Is Over.” Comparative Politics 43(1), 41-61.

Dahl, Robert A. 1971. Polyarchy. New Haven: Yale University Press.

Dalton, Russell. 2013. Citizen Politics. Thousand Oaks: CQ Press.

Dalton, Russell, and Christian Welzel. 2014. Civic Culture Transformed. New York: Cambridge University Press.

Diamond, Larry. 1999. Developing Democracy. Baltimore: Johns Hopkins University Press.

Gibson, James L. 1996. "A Mile Wide But an Inch Deep: The Structure of Democratic Commitments in the Former USSR.” American Journal of 
Political Science 40(2), 396-420.

Gibson, James L., Raymond M. Duch, and Kent L. Tedin. 1992. "Democratic Values and the Transformation of the Soviet Union." Journal of Politics 54(2), 329-371.

Huntington, Samuel P. 1981. American Politics. Cambridge: Belknap Press.

Inglehart, Ronald. 2003. "How Solid Is Mass Support for Democracy: And How Can We Measure It?" PS: Political Science and Politics 36(1), 51-57.

Inglehart, Ronald and Christian Welzel. 2005. Modernization, Cultural Change, and Democracy. New York: Cambridge University Press.

Jackman, Robert W. and Ross A. Miller. 1996. "A Renaissance of Political Culture?” American Journal of Political Science 40(3), 632-659.

Kornberg, Allan and Harold Clarke. 1992. Citizens and Community. New York: Cambridge University Press.

Lipset, Seymour. 1960. Political Man. Garden City: Doubleday.

Muller, Edward. 1977. "Behavioral Correlates of Political Support." American Political Science Review 71(2), 454-467.

Munck, Gerardo L. 2009. Measuring Democracy. Baltimore: Johns Hopkins University Press.

Nathan, Andrew J., and Tianjian Shi. 1993. "Cultural Requisites for Democracy in China: Findings from a Survey.” Daedalus 122(2), 95-123.

Norris, Pippa. 1999. Critical Citizens. New York: Oxford University Press. 2002. Democratic Phoenix. New York: Cambridge University Press. . 2011. Democratic Deficit. New York: Cambridge University Press.

O’Donnell, Guillermo, Philippe C. Schmitter, and Laurence Whitehead. 1986. Transitions from Authoritarian Rule. Baltimore: Johns Hopkins University Press.

Petty, Richard, and Jon Krosnick. 1994. Attitude Strength. Hillsdale: Erlbaum.

Putnam, Robert D. 1993. Making Democracy Work. Princeton: Princeton University Press. 2000. Bowling Alone. New York: Simon and Schuster.

Raudenbush, Stephen W., and Anthony S. Bryk. 2002. Hierarchical Linear Models. London: Sage.

Rose, Richard, William Mishler, and Christian Haerpfer. 1998. Democracy and Its Alternatives. Baltimore: Johns Hopkins University Press.

Rueschemyer, Dietrich, Evelyne Huber Stephens, and John D. Stephens. 1992. Capitalist Development and Democracy. Chicago: University of Chicago Press.

Steenbergen, Marco R. and Bradford S. Jones. 2002. "Modeling Multilevel Data Structures." American Journal of Political Science 46(1), 218-237. 
D emocratic Attitudes and Political Participation in the D eveloping World | 83

Verba, Sidney, Kay Lehman Schlozman, and Henry E. Brady. 1995. Voice and Equality. Cambridge: Harvard University Press.

Welzel, Christian. 2013. Freedom Rising. New York: Cambridge University Press.

[Received February 5, 2015; Revised April 7, 2015; Accepted April 16, 2015] 


\section{Appendix A. Survey Questions and Macro-Level Variables}

\section{Democratic Attitudes \\ Affection: Democratic Support}

I'm going to describe various types of political systems and ask what you think about each as a way of governing this country. For each one, would you say it is a very good, fairly good, fairly bad, or very bad way of governing this country?

V148. Having a strong leader who does not have to bother with parliament and elections

V150. Having the army rule

V151. Having a democratic political system

Cognition: Democratic Understanding

Many things may be desirable, but not all of them are essential characteristics of democracy. Please tell me for each of the following things how essential you think it is as a characteristic of democracy. Use this scale where 1 means "not at all an essential characteristic of democracy" and 10 means it definitely is "an essential characteristic of democracy"

V153. Religious authorities interpret the laws.

V154. People choose their leaders in free elections.

V156. The army takes over when government is incompetent.

V157. Civil rights protect people's liberty against oppression.

Conation: Willingness to Live in Democracy

V162. How important is it for you to live in a country that is governed democratically? On this scale where 1 means it is "not at all important" and 10 means "absolutely important," what position would you choose?

Political Participation

Conventional Participation: Voting

V234. Did you vote in your country's recent elections to the national parliament?

\section{Unconventional Participation}

Now here are some forms of political action that people can take. Please indicate, for each one, whether you have done any of these things, whether you might do it or would never do it under any circumstances. 
V96. Signing a petition/V97. Joining in boycotts

Resource Model

Education

V238. What is the highest educational level that you have attained?

Income

V253. On this card is a scale of incomes on which 1 indicates the "lowest income decile" and 10 the "highest income decile" in your country. I would like to know in what group your household is. Please, specify the appropriate number, counting all wages, salaries, pensions and other income you receive.

Media Use (A Composite Index)

People use different sources to learn what is going on in their country and the world. For each of the following sources, please indicate whether you used it last week or did not use it last week to obtain information:

V223. Daily newspaper/V224. News broadcasts on radio or TV

\section{Social Capital Model}

Membership in Civic Organizations (A Composite Index)

Now I am going to read off a list of voluntary organizations. For each one, could you tell me whether you are an active member, an inactive member or not a member of this type of organization?

V25. Sports or recreational organization/V26. Art, music, or educational organization

V29. Environmental organization/V31. Humanitarian or charitable organization

Political Trust (A Composite Index)

I am going to name a number of organizations. For each one, could you tell me how much confidence you have in them: is it a great deal of confidence, quite a lot of confidence, not very much confidence, or none at all?

V138. The government/V139. Political Parties/V140. Parliament

Interpersonal Trust

V23. Generally speaking, would you say that most people can be trusted or that you need to be very careful in dealing with people? 


\section{Political Culture Model}

Self-Expression Values (A composite index)

For each of the following statements I read out, can you tell me how strongly you agree or disagree with each. Do you strongly agree, agree, disagree, or strongly disagree?

V61. On the whole, men make better political leaders than women do.

V62. A university education is more important for a boy than for a girl.

Do you agree, disagree or neither agree nor disagree with the following statements?

V44. When jobs are scarce, men should have more right to a job than women.

V59. If a woman wants to have a child as a single parent but she doesn't want to have a stable relationship with a man, do you approve or disapprove?

Please tell me for each of the following actions whether you think it can always be justified, never be justified, or something in between, using this card.

V202. Homosexuality/V204. Abortion/V205. Divorce

V69. People sometimes talk about what the aims of this country should be for the next ten years. On this card are listed some of the goals to which different people would give top priority. Would you please say which one of these you consider the most important?

V7o. And which would be the next most important?:

A high level of economic growth/Making sure this country has strong defense forces/Seeing that people have more say about how things are done at their jobs and in their communities/Trying to make our cities and countryside more beautiful

V71. If you had to choose, which one of the things on this card would you say is most important?

V72. And which would be the next most important?

Maintaining order in the nation/Giving people more say in important government decisions

Fighting rising prices/Protecting freedom of speech

Here is a list of qualities that children can be encouraged to learn at home. Which, if any, do you consider to be especially important? 
V12. Independence/V15. Imagination/V19. Religious faith/V21. Obedience For each of the following, indicate which you believe are the most important in your life.

V4. Family/V5. Friends/V6. Leisure time/V8. Work

Other Control Variables

Political Interest

V95. How interested would you say you are in politics?

Country-Level Variables

Freedom House Rating — Freedom House Organization

GDP per Capita - CIA World Factbook 